\title{
Reflections
}

\section{From cyberspace to cyberspatialities?}

\author{
DANIELA FERREIRA AND MÁRIO VALE
}

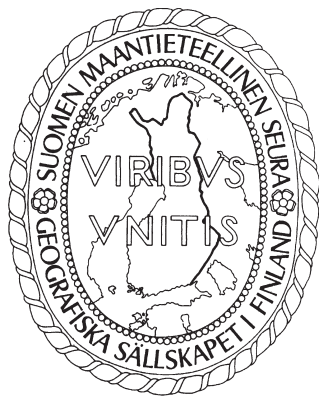

Ferreira, D. \& Vale, M. (2021) From cyberspace to cyberspatialities? Fennia 199(1) 113-117. https://doi.org/10.11143/fennia.100343

This paper is a short reflection on the evolution of the meaning of the term cyberspace for geographers. We argue that the concept of cyberspace has become a rhizomatic one as spatial thinkers have unveiled its complex inner and outer networkings. While cyberspace was initially understood as a new open space ripe for exploration, its intricate connections with real space through the technological infrastructures that make cyberspace possible have led geographers to consider the multiple points of access and types of cyberspace. More recently, there has been renewed attention to the inner geographies of cyberspace and its cyberdivides have been exposed. We briefly retrace this evolution to argue that the way forward is to shift from an idea of cyberspace as a predefined space to a notion of cyberspatialities as ongoing spatial digital formations.

Keywords: cyberspace, virtual space, cyberdivides, cyberspatialities, digital geographies

Daniela Ferreira (https://orcid.org/0000-0003-1541-4161) \& Mário Vale (https://orcid.org/0000-0002-4548-2459), Centre of Geographical Studies, Institute of Geography and Spatial Planning, Universidade de Lisboa. R. Branca Edmée Marques, 1600-276, Lisbon, Portugal. E-mail: danielaferreira2@campus.ul.pt,mario.vale@campus.ul.pt

Cyberspace had a profound impact on the way human societies are organized and contemporary life is inextricable from its effects. The concept of cyberspace itself has a considerably rich history; one which has provoked serious debates in science, philosophy, and the arts. In geography, the concept was initially received with a mix of interest and scepticism. The interest stemmed from its obvious impact on all forms of human living. Geographers had been attentive to the development of new technologies of information and communication since the 1960s. For Evans (1979), there was an enthusiasm around the capacity of "mighty micro" to revolutionize our way of life and some futurist terms emerged to refer to this revolution, such as Toffler's (1980) "Third Wave", Drucker's (1993) fourth revolution, or Bell's (1979) post-industrial society focused on information. During the mid1990s, the democratization of the internet created some discussion around the new society that could be emerging (Negroponte 1995). Advances in telecommunications created 'information superhighways' and, as a consequence, internet technologies were rapidly adopted. Some argued that this new order created a placeless connectivity where we could access any place anytime (Webster 2006). This led to a transition to new economic activities, which allowed changes in the model of

URN:NBN:fi:tsv-oa100343

DOI: $10.11143 /$ fennia.100343 (cc) BY (c) 2021 by the author. This open access article is licensed under a Creative Commons Attribution 4.0 International License. 
economic growth. The emergence of innovations and the globalization context, along with the new techno-economic paradigm, created the conditions for the society of information or the information age (Hall \& Preston 1988; Preston 2001), which was the subject of wide discussion (Castells 2000). Some argued that the information society had not been reached yet (Martin 1995), while others believed it had already begun in the 1980s (Kellerman 2002). Despite this, the practical effects of the adoption of the internet as a crucial means of communicating and accessing information were widely acknowledged. Castells and Hall (1994) considered that technopoles were changing their structure due to the appearance of a new economy in advanced industrial countries, characterized by a new form of production, consumption and management based in new ways of knowledge transmission through information and communication technologies. This new economy changed the spatial patterns of companies through processes of compression and dispersion (Graham \& Marvin 2001). Furthermore, infrastructure and digital devices started to be integrated within cities and, during this process, the service sector became the main sector of economy in Western world (Webster 2006).

Geographers greatly contributed to the comprehension of the spatial changes induced by the internet. Several works on the geographies of information and technologies were published in the first half of the 1990s, such as Goddard's (1992) work on the geography of information and regional and urban development, Hepworth's (1990) work on the geographies of computers and information technologies, Kellerman's (1993) and Graham and Marvin's (1995) work on the geographies of telecommunications, or Feldman's (1994) work on the geography of innovation. However, these works argued against the widespread notion that the internet had rendered space meaningless and that all physical barriers had been overcome, as if proximity does not matter anymore (Morgan 2004). Geographers recognized that some distances had become shorter, especially when physical services became online services, such as the case of mail (Harvey 1991; Webster 2006; Vale 2009). However, it was also argued that the access to information was not equal for all. Some authors were concerned with the growing inequalities associated with the access to technologies, which led to the emergence of the concept of digital divide. It was noted that such divide was not merely digital; it was rooted in social, economic, and spatial divides (Dodge \& Kitchin 2002). Such concerns remain to this day as the proliferation of smartphones and digital platforms has recently led to a questioning of how and for whom digitally mediated knowledge is produced (Graham 2011; Kleine 2013).

Going back to the 1990s, geographers were also wary of the language being used to describe the characteristics of internet, which included a great number of spatial metaphors. It is important to highlight that while these grand concepts were being conceived, geography was undergoing new theoretical developments. Postmodernism was the first important moment in poststructuralist geography and the beginning of the new paradigm, a new way of thinking about the world (Ferreira \& Vale 2020). It implied careful consideration of how spaces are socially constructed and imbued with meaning through the placement of symbols and narratives. In this context, the use of spatial metaphors such as information highway, virtual community, electronic frontier, websurfers, libraries, fora, or lobbies to refer to the hyperspace of the internet was contested by geographers (Pile 1994; Adams 1997). Cyberspace was one of such terms, and indeed the question if whether cyberspace is an actual space or a mere metaphor remains to this day (Kellerman 2020), although it has been acknowledged that this language fostered a sense of community, place or belonging regarding different virtual media (Paiva 2015).

For this reason, cyberspace has become a significant topic of research for geographers since then. Several geographic studies have approached the concept of cyberspace in studies of the geographies of internet, cyber geography, geography of cyberspace, and virtual geography (Batty 1997; Kitchin 1998a, 1998b; Crang et al. 1999; Dodge \& Kitchin 2002; Kellerman 2002). Some of these studies were influenced by humanistic concerns and these focused specially in discussions on the cyberspace experience. While humanist geography was focused on the real places and its experience, over the years this perspective has underpinned some studies on sense of place and community in virtual spaces. For instance, Kwan $(2001,23)$ argued that "an individual's experience of using the internet may engender a sense of "place" or "community"'." However, others such as Bolter and Grusin (1999) viewed cyberspace as a non-place using Augé's (2000) concept. Since then, geographers have leaned toward understanding some virtual spaces as places (Relph 2007; Paiva 2015). 
On the other hand, geographers influenced by poststructuralist thought, actor-network theory, feminism, and non-representational theory have conceived cyberspace as social technical network that stem from the assemblage of places, infrastructures, interfaces, individuals, and so on (Graham 1998; Kellerman 2016; Ash et al. 2018). Different definitions of cyberspace have been made under these perspectives. First, there is the definition of artificial reality. Some geographers have argued that since cyberspace is based on computers and sustained by a global network, it is therefore a virtual or artificial reality (Benedikt 1991; Kitchin 1998a). Instead, Batty (1997) argued that cyberspace is a space of interactivity and it is not exactly an imagined space because it can be real when the users use the computer to communicate. Dodge and Kitchin (2002) believe that cyberspace is a conceptual space integrated on Information and Communication Technologies (ICTs), and not only the technology itself. However, some authors such as Graham (2013) still contend that cyberspace remains a geographical metaphor.

More recently, cyberspace has been considered a segment of image space. For geography, the concept of image space was considered initially as mental images, meaning it referred to the imagined spaces in our minds expressed through maps and illustrations (Phillips 1993). But now, there are new ways to create image space and cyberspace is considered the foremost method to do so (Ash 2009). According to Kellerman (2016), within image space there are three classes ranging from broader concepts to more specific ones. These concepts are (in descending order of coverage): virtual space, cyberspace, and the internet.

Virtual space concept is the widest term and it includes all others. Crang, Crang and May (1999) define virtual space as a digital simulation similar to a space where there is a relation among screen and body. Virtual space is the result between the combinations of two types of space: abstract and relative space supported by infrastructures (Zook et al. 2004). The concept of cyberspace is one of the subsets of virtual space (Kellerman 2016). Initially, cyberspace was seen as a science-fiction notion and later it was applied to ICTs. Gibson $(1984,51)$ referred that cyberspace is defined as a "consensual hallucination", a graphic representation of abstract data. Benedikt $(1991,15)$ and Grosz $(2001)$ argue that it is a "parallel universe" and Batty $(1993,615)$ defines cyberspace as a "new kind of space, invisible to our direct senses, a space which might become more important than physical space itself. (...) it is layered on to, within and between the fabric of traditional geographical space." The last image space is the internet, which is constituted by three subsets of spaces that integrate cyberspace. Firstly, there is internet information space which refers to the information which is stored in sets, sites or systems within the internet (Fabrikant \& Buttenfield 2001). Secondly, the internet communications space which concerns the cyberspace of individuals. In this kind of space, it is possible to communicate through various ways, such as WhatsApp, Snapchat, Facebook, or Twitter. Thirdly, there is the internet screen-space that can be defined as the interfaces between the information and communication space and the user, which can be a PC screen, or a smartphone, for instance. These screen-spaces include a great variety of visual forms: texts, graphics, images, or hypertextual media that combine different elements (Zook et al. 2004).

While the conception of cyberspace itself has become a stable one in the last decade, the growing geographic literature on the topic has unveiled the complex topographies of cyberspace. For instance, Graham (2011) draws attention to the series of elements that promote cyberdivides. On one hand, governmental or private entities can render certain parts of the internet inaccessible, such as the case of China or North Korea (Faris et al. 2008). The actions of the French government to restrict online content on periods of World War II are also an example of such barriers that generate cyber divisions (Drissel 2006). In addition, there is software specifically developed to limit internet access to approved content, especially for children, companies and schools. These examples show that the division within virtual space is more complex than what the binary definition of digital divide based on access and non-access suggests. Graham (2011) also points to cultural differences as an influence on interaction and access to content. Namely, language can be considered one of the biggest barriers to access to different types of content. It is likewise necessary to take the context and positionality of information on the internet into account. That is, information on the internet can be interpreted differently according to the aesthetic and emotional relationships that readers establish with such information. In addition to content restrictions and cultural barriers, it is also important to note that platform 
capitalism has generated a new layer of cyber divisions by creating instruments that influence online visibility. As online information in digital platforms has become nearly unlimited, it has also become impossible to access all the information and know everything that is available in a virtual environment. In this context, several mechanisms have emerged to give more visibility to certain contents, making many others invisible. There are processes of classification and hierarchization of content, as well as the application of search algorithms that exacerbate this difference between the visible and the invisible in the online environment (Zook \& Graham 2007).

Thus, cyberspace is by no means an overcoming of actual space or a wide open space free to roam for everybody. Instead, it is a complex concept that is interweaved with everyday life and the real world. It contains its own topographies, divides, and place meanings, most of which stem from but also change the real world. In this sense, cyberspace is not a stable space that is already there. It is an ongoing and highly performative process constituted by temporary assemblages of data, people, devices, infrastructure and space. It is the never-ending product of cyberspatialities, that is, the uneven cyber spatial formations of materialities, such as technologies and interfaces, and immaterialities, such as data and representations, that always produce something new. Those cyberspatialities, rather than the technological possibility of cyberspace itself, are what has profoundly changed the economy and the society in the last three decades, and so it should be a significant object of our concern for the foreseeable future.

\section{Acknowledgements}

This work was supported by the Fundação para a Ciência e a Tecnologia [SFRH/BD/131253/2017]; and the Centre of Geographical Studies [UIDB/00295/2020], [UIDP/00295/2020].

\section{References}

Adams, P. C. (1997) Cyberspace and virtual places. Geographical Review 87 (2) 155-171. https://doi.org/10.2307/216003

Ash, J. (2009) Emerging spatialities of the screen: video games and the reconfiguration of spatial awareness. Environment and Planning A 41(9) 2105-2124. https://doi.org/10.1068/a41250

Ash, J., Kitchin, R. \& Leszczynski, A. (2018) Digital turn, digital geographies? Progress in Human Geography 42(1) 25-43. https://doi.org/10.1177/0309132516664800

Augé, M. (2000) Non-places: Introduction to an Anthropology of Supermodernity. Verso, London.

Batty, M. (1993) The geography of cyberspace. Environment and Planning B: Planning and Design 20(6) 615-616. https://doi.org/10.1068/b200615

Batty, M. (1997) Virtual geography. Futures 29(4-5) 337-352. https://doi.org/10.1016/S0016-3287(97)00018-9

Bell, D. (1979) The social framework of the information society. In Dertouzous, M. \& Moses, L. (eds.) The Computer Age: A Twenty-Year View, 163-211. MIT Press: Cambridge.

Benedikt, M. (1991) Introduction. In Benedikt, M. (ed.) Cyberspace: First Steps, 1-18. MIT Press, Cambridge.

Bolter, J. D. \& Grusin, R. (1999) Remediation: Understanding New Media. MIT Press, Cambridge.

Castells, M. (2000) The Rise of The Network Society, The Information Age: Economy, Society and Culture. Blackwell Publishers, Oxford.

Castells, M. \& Hall, P. (1994) Technopoles of the World: The Making of 21st Century Industrial Complexes. Routledge, New York.

Crang, M., Crang, P. \& May, J. (1999) Virtual Geographies - Bodies, Space and Relations. Routledge, London.

Dodge, M. \& Kitchin, R. (2002) Mapping Cyberspace. Routledge, London. https://doi.org/10.4324/9780203165270

Drissel, D. (2006) Internet governance in a multipolar world: challenging American hegemony. Cambridge Review of International Affairs 19(1) 105-20. https://doi.org/10.1080/09557570500501812

Drucker, P. (1993) Post-Capitalist Society. Harper Collins, New York.

Evans, C. (1979) The Mighty Micro: The Impact of the Computer Revolution. Gollancz, London.

Fabrikant, S. I. \& Buttenfield, B. (2001) Formalizing semantic spaces for information access. Annals of the Association of American Geographers 91(2) 263-280. https://doi.org/10.1111/0004-5608.00242

Faris, R., Wang, S. \& Palfrey, J. (2008) Censorship 2.0. Innovations 3(2) 165-187. https://doi.org/10.1162/itgg.2008.3.2.165

Feldman, M. P. (1994) The Geography of Innovation. Kluwer, Dordrecht. https://doi.org/10.1007/978-94-017-3333-5 
Ferreira, D. \& Vale, M. (2020) Geography in the big data age: an overview of the historical resonance of current debates. Geographical Review [online Oct 22 2020] https://doi.org/10.1080/00167428.2020.1832424

Gibson, W. (1984) Neuromancer. Harper and Collins, London.

Goddard, J. (1992) New technology and the geography of the UK information economy. In Robins, K. (ed.) Understanding Information Business, Technology and Geography, 178-201. Belhaven, London.

Graham, M. (2011) Time machines and virtual portals: the spatialities of the digital divide. Progress in Development Studies 11(3) 211-227. https://doi.org/10.1177/146499341001100303

Graham, M. (2013) Geography/Internet: ethereal alternate dimensions of cyberspace or grounded augmented realities? The Geographical Journal 179(2) 177-182. https://doi.org/10.1111/geoj.12009

Graham, S. (1998) The end of geography or the explosion of place? Conceptualizing space, place and information technology. Progress in Human Geography 22(2) 165-185. https://doi.org/10.1191/030913298671334137

Graham, S. \& Marvin, S. (1995) Telecommunications and the City: Electronic Spaces, Urban Places. Routledge, London.

Graham, S. \& Marvin, S. (2001) Splintering Urbanism. Networked Infrastructures, Technological Mobilities and the Urban Condition. Routledge, London. https://doi.org/10.4324/9780203452202

Grosz, E. (2001) Architecture from the Outside: Essays on Virtual and Real Space. MIT Press, Cambridge.

Hall, P. \& Preston, P. (1988) The Carrier Wave: New Information Technology and the Geography of Innovation, 1846-2003. Unwin Hyman, Boston, MA.

Harvey, D. (1991) The Condition of Postmodernity: An Enquiry into the Origins of Cultural Change. Blackwell, Oxford.

Hepworth, M. (1990) Geography of the Information Economy. Guilford, New York. https://doi.org/10.3406/netco.1990.1055

Kellermann, A. (1993) Telecommunications and Geography. Belhaven, London.

Kellerman, A. (2002) The Internet on Earth: A Geography of Information. Wiley, London.

Kellermann, A. (2016) Geographic Interpretations of the Internet. Springer, London. https://doi.org/10.1007/978-3-319-33804-0

Kellerman, A. (2020) Is cyberspace there after all? In Warf, B. (ed.) Geographies of the Internet, 19-33. Routledge, Abingdon. https://doi.org/10.4324/9780367817534-3

Kleine, D. (2013) Technologies of Choice? ICTs, Development, and the Capabilities Approach. MIT Press, Cambridge. https://doi.org/10.7551/mitpress/9061.001.0001

Kitchin, R. (1998a) Cyberspace: The world in the Wires. Wiley, Chichester.

Kitchin, R. (1998b) Towards geographies of cyberspace. Progress in Human Geography 22(3) 385-406. https://doi.org/10.1191/030913298668331585

Kwan, P. (2001) Cyberspatial cognition and individual access to information: the behavioural foundation of cybergeography. Environment and Planning B 28(1) 21-37. https://doi.org/10.1068/b2560

Martin, W. J. (1995) The Global Information Society. Gower Pub Co, London.

Morgan, K. (2004) The exaggerated death of geography: learning, proximity and territorial innovation systems. Journal of Economic Geography 4(1) 3-21. https://doi.org/10.1093/jeg/4.1.3

Negroponte, N. (1995) Being Digital. Alfred A. Knopt, New York.

Paiva, D. (2015) Experiencing virtual places: insights on the geographies of sim racing. Journal of Cultural Geography 32(2) 145-168. https://doi.org/10.1080/08873631.2014.978128

Phillips, R. S. (1993) The language of images in geography. Progress in Human Geography 17(2) 180-194. https://doi.org/10.1177/030913259301700203

Pile, S. (1994) Cybergeography: 50 years of Environment and Planning A. Environment and Planning A 26 1815-1823.

Preston, P. (2001) Reshaping Communications: Technology, Information and Social Change. Sage, London.

Relph, E. (2007) Spirit of place and sense of place in virtual realities. Techné: Research in Philosophy and Technology 10(3) 17-25. https://doi.org/10.5840/techne20071039

Toffler, A. (1980) The Third Wave. William Morrow, New York.

Webster, F. (2006) Theories of The Information Society. Routledge, London. https://doi.org/10.4324/9780203962824

Vale, M. (2009) Conhecimento, Inovação e Território. Finisterra - Revista Portuguesa de Geografia $\mathrm{XLIV}(88)$ 9-22.

Zook, M. \& Graham, M. (2007) Mapping DigiPlace: geocoded internet data and the representation of place. Environment and Planning B: Planning and Design 34(3) 466-482. https://doi.org/10.1068/b3311

Zook, M., Dodge, M., Aoyama, Y. \& Townsend, A. (2004) New digital geographies: information, communication, and place. In Brunn, S., Cutter, S. \& Harrington J. (eds.) Geography and Technology, 155-176. Kluwer, Dordrecht. https://doi.org/10.1007/978-1-4020-2353-8 7 